\title{
ЛИТОСТРАТИГРАФИЧЕСКАЯ МОДЕЛЬ СРЕДНЕЮРСКИХ ОТЛОЖЕНИЙ (С УЧЕТОМ ПАЛЕОГЕОГРАФИИ) ЗАПАДНЫХ РАЙОНОВ ТОМСКОЙ ОБЛАСТИ И ЮГО-ВОСТОЧНЫХ РАЙОНОВ ХАНТЫ-МАНСИЙСКОГО АВТОНОМНОГО ОКРУГА
}

Золотова О.В.

(Институт нефтегазовой геологии и геофизики ин.А.А.Трофилика СО РАН)

При выявления и картировании нефтегазоперспективньг объектов в отложенкях среднеюрского комплекса важно представлять, какие палеогеографические об̆становки были наиболее благоприятными для формирования песчаных отложений, способных служить резервуарами для залежей углеводородов.

Проницаемый комплекс среднеюрских отложений выделяется в объеме от кровли тюменской свиты до кровли угля $\mathrm{Y}_{10}$ и объединяет песчаные пласты $\mathrm{Ю}_{2}-Ю_{10}$. На исследуемой территории комплекс полностью вскрьт 264 скважинами и имеет в них толщину от 5 м на западе до 272 м в восточной, северной и северозападной частях рассматриваемой территории. В югозападном и западном направлениях фиксируется уменьшение толщины резервуара, до полного его исчезновения. На фоне охарактеризованного регионального характера изменения толщины резервуара отмечается значительное колебание этого показателя на крупных структурах. В наиболее прогнутых частях отрицательных структур его значения максимальные, а в сводовых частях поднятий - минимальные. Глубина залегания кровли проницаемого комплекса по картографическим построениям - от 2200 до 3250 м. Характер ее распределения по площади похож на характер изменения толпины резервуара. Минимальные отметки кровли расположены полосой с юго-запада на северо-восток. Максимальные отметки наблюдаются на северо-западе, юго-востоке и востоке территории. Фациальный состав отложений проницаемого комплекса весьма разнообразный - от континентальных (аллювиальньх равнин) до прибрежно-морских. Снизу вверх по разрезу отмечается возрастание мористости отложений. Условия формирования песчаньгх разностей проницаемого комплекса весьма разнообразные. Наибольшая нх часть на западе района образовалась в обстановках прибрежного мелководья и заливнолагунного побережья, на востоке в русловой части рек. Западная часть Томской области характеризуется развитием аллювиальньх, озерных, болотньг образований: конгломератов, гравелитов, разнозернистых песчаников, алевролитов, аргиллитов, угольных пластов В юго-восточной части ХMAO и северо-восточной части Омской области осадки формировались в мелководной части шельфа, на дельтовьг платформах и их склонах, в лагунах, на прибрежно-морских равнннах, занятых озерами, болотами, низовьями речнпьх долин. На морские обстановки указывают особенности литологического состава пород верхней части тюменской свиты: обилие ходов илоедов, повыпенное содержание пирита, находки микрофауны сходного состава на огромной территории, что указывает на мелководноморской режим седиментации. В то же время большое количество углистого растительного детрита, прослои углей, остатки корней растений, комковатые текстуры, отсутствие выдержанных глинистых пачек свидетельствует о наличия прослоев континентального генезиса и крайне мелководном режиме морского бассейна Флюидоупором для данного проницаемого комплекса является аргиллитистая пачка нижневасюганской под- свиты, которая на большей части территорни образованиями глубокой части шельфа. Минимальная толшина пачки составляет 6 м и максимальная 66 м. Нанбольшая толщина флюидоупора зафиксирована на двух обширньт участках, имеющих полосовидную форму. Один кз них, ориентированный в северо-восточном направлении, простирается от Ледового куполовидного поднятия вдоль западного борта Хантейской гемиантиклизы. Другой участок, имеющий ссвсро-восточнос простирание, протягивается по осевой части Колтогорско-Нюрольского желоба. Литологический состав флюидоупора изменчив по площади района. Разрез флюидоупора представлен глинами аргиллитоподобными, часто тонкоотмученными темно-серыми с буроватьм оттенком с прослоями алевролитов и песчаников, сформировавшимися в относительно глубоководной части шельфа. Анализ комплекса показателей, влияющих на экранирующие свойства флюидоупора, позволяет в пределах изучаемого района выделить зоны различного его качества - от высокого до низкого. Земли с высоким качеством флюидоупора расположены в западной, юго-западной и северо-западной частях изучаемого района. Земли со средним качеством экрана распространены на северо-востоке и в центральной части. Пониженное качество флюидоупора фиксируется в основном в восточной и юго-восточной части района. Качество флюидоупора в значительной мере определяет региональную нефтеносность среднеюрских отложений. Выявленные палеогеографические обстановки и основные закономерности пространственного размещения отложений позволяют наметить зоны отложения в которых обладают наиболее благоприятными коллекторскими свойствами, а так же зоны выклинивания этих отложений, $\mathrm{k}$ которым могут быть пркурочены литологические ловушки нефти и газа. На исследуемой территории выделены две основные палеогеографические области. Западная часть изучаемого района (преимущественно территория Томской области) представляла собой равнину с широким развитием речной сети и характерньми для этой области русловым и водораздельным типами разрезов (территория Каймысовского и Нижневартовского сводов). Восточная часть - это опреснённый бассейн с бассейновым типом разреза. В зоне перехода от аллювиальной равнины к бассейну выделяется область прибрежной равнины с устьевыми выносами рек, для которой характерен полифациальный комплекс, формировавшийся в условиях, переходных от континентальных к морским. 